Published in final edited form as:

Microbiol Spectr. 2017 January ; 5(1): . doi:10.1128/microbiolspec.TNMI7-0035-2016.

\title{
Endocrine and Metabolic Aspects of Tuberculosis
}

\author{
Christopher Vinnard ${ }^{1}$ and Emily A. Blumberg ${ }^{2}$ \\ ${ }^{1}$ The Public Health Research Institute Center and Department of Medicine, New Jersey Medical \\ School, Rutgers, The State University of New Jersey, Newark, NJ 07103 \\ ${ }^{2}$ Division of Infectious Diseases, Department of Medicine, Perelman School of Medicine at the \\ University of Pennsylvania, Philadelphia, PA 19104
}

\begin{abstract}
Endocrine and metabolic derangements are infrequent in patients with tuberculosis, but they are important when they occur. The basis for these abnormalities is complex. While Mycobacterium tuberculosis has been described to infect virtually every endocrine gland, the incidence of gland involvement is low, especially in the era of effective antituberculosis therapy. Furthermore, endocrine and metabolic abnormalities do not always reflect direct infection of the gland but may result from physiological response or as a consequence of therapy. Metabolic disease may also predispose patients to the development of active tuberculosis, particularly in the case of diabetes mellitus. While hormonal therapy may be necessary in some instances, frequently these endocrine complications do not require specific interventions other than antituberculous therapy itself. With the exception of diabetes mellitus, which will be covered elsewhere, this chapter reviews the endocrinologic and metabolic issues related to tuberculosis.
\end{abstract}

\section{ADRENAL GLAND MANIFESTATIONS}

Tuberculosis may lead to adrenal insufficiency by direct glandular involvement, by extraadrenal infection, or as a by-product of antituberculous therapy. When primary adrenal insufficiency is a product of direct glandular involvement, signs and symptoms may not appear until more than $90 \%$ of the gland has been destroyed. Bilateral adrenal cortex destruction leads to a deficiency in the production of glucocorticoids, mineralocorticoids, and androgens.

In Addison's original description of 11 patients with the constellation of findings that characterizes primary adrenal insufficiency, 6 patients had adrenal tuberculosis. In a review of the adrenal pathology of 566 cases of Addison's disease in 1930, tuberculous adrenalitis was observed in $70 \%$ of cases (1). In areas where the incidence of tuberculosis has declined, the role of tuberculosis as a cause of Addison's disease has likewise decreased, and more recent estimates suggest that tuberculosis accounts for 10 to $15 \%$ of cases of Addison's disease (2). 
Several patterns of direct adrenal gland involvement have been described. Primary adrenal insufficiency usually results from chronic infection of the adrenal gland with $M$.

tuberculosis, with clinical manifestations becoming apparent years after the initial presentation. Less commonly, adrenal insufficiency may occur as an isolated manifestation of early adrenal involvement (1).

There are four classic histopathological patterns of adrenal tuberculosis: caseating or noncaseating granulomas, glandular enlargement with adrenal destruction by inflammatory granulomas, mass lesions secondary to the development of cold abscesses, and adrenal atrophy from fibrosis related to chronic infection (3). Epithelioid granulomas occur less frequently in the adrenals than in extra-adrenal foci, possibly reflecting the local production of anti-inflammatory steroids (4). Calcification of the gland is a common but not specific finding. Although descriptions of adrenal tuberculosis often focus on cortical involvement, it is important to note that the medulla may also be involved.

Adrenal tuberculosis results from early hematogenous spread; consequently, it is often associated with extra-adrenal infection. In a large autopsy series from Hong Kong, $6 \%$ of patients with active tuberculosis had evidence of adrenal infection, and in one-fourth of these patients, infection was isolated to the adrenal glands (5). Other case series have found isolated adrenal tuberculosis in $3 \%$ of all patients with tuberculosis $(1,6)$. When infection is not isolated to the adrenals, the most common extra-adrenal manifestations are pulmonary and genitourinary tuberculosis (3). While both adrenal glands are usually involved, they may not be equally affected $(3,7,8)$.

Adrenal insufficiency should be verified by demonstrating depressed morning plasma cortisol levels with a diminished response to synthetic adrenocorticotropin (ACTH) $(9,10)$. Differences in the methods of assessment of adrenal insufficiency have led to a wide range in the reported incidence of pretreatment adrenal insufficiency. When adrenal function is measured appropriately in patients with tuberculosis prior to treatment, primary adrenal insufficiency is uncommonly found (11-14). An impaired ACTH response has sometimes been observed in the setting of an elevated basal cortisol level, but the clinical significance of this finding is uncertain $(15,16)$. In some cases of isolated pulmonary tuberculosis without specific adrenal involvement, ACTH-stimulated cortisol responses may be affected with reports of lower baseline cortisol levels and both higher and lower cortisol responses to ACTH stimulation $(17,18)$.

The possibility of adrenal tuberculosis should be considered when patients with a history of tuberculosis, either active disease or a positive tuberculin skin test, present with the classic manifestations of adrenal insufficiency: malaise, anorexia, orthostatic hypotension, and hyperpigmentation. Laboratory abnormalities may include anemia, hyponatremia, and hyperkalemia. While human immunodeficiency virus (HIV) is also a cause of adrenal insufficiency, HIV infection did not confer an additional risk of adrenal insufficiency among tuberculosis patients in a study of patients in Kenya (19). Rarely, patients may present with the acute onset of life-threatening adrenal insufficiency $(20,21)$. 
Radiographic imaging, including computed tomography (CT), magnetic resonance imaging (MRI), and positron emission tomography, is a useful noninvasive adjunct to diagnosis, although it does not provide definitive diagnosis (22). Typically, adrenal involvement is bilateral and imaging varies based on the stage of the disease. During the first 2 years of illness, the most common CT findings include noncalcified, enlarged adrenal glands with areas of lucency reflecting caseous necrosis; this may appear as peripheral rim enhancement following contrast administration (22-25). With chronic infection, the typical CT appearance is of shrunken adrenal glands, often with associated calcifications and irregular margins. The incidence of calcifications increases with the duration of illness, and their presence on CT imaging increases the likelihood of a diagnosis of tuberculosis (26). MRI scans may also provide useful clues to the diagnosis, with findings similar to those described for CT imaging, although calcifications are more clearly seen on CT scans (22). MRI findings include hypointense or isointense areas on T1 and hyperintense areas on T2 weighted images. In a single study of Chinese patients with proven adrenal tuberculosis, 83\% of glands demonstrated peripheral enhancement on contrast MRI (27). Treatment may alter imaging characteristics of earlier disease, but adrenal glands irreversibly damaged by infection show persistence of abnormalities (22). There are fewer data regarding positron emission tomography imaging for patients with tuberculosis; enhancement with fluorodeoxyglucose similar to that seen with malignancy has been described previously (28).

The differential diagnosis for adrenal enlargement includes malignancy, hemorrhage, fungal infection, amyloidosis, sarcoidosis, adenoma, hemangioma, and hyperplasia. Whenever possible, tissue specimens should be obtained for microbiological and pathological analyses, especially in cases in which adrenal involvement is the only evidence of tuberculosis. CTguided needle aspiration of the adrenal gland has successfully provided adequate tissue specimens for diagnosis (7, 23, 29). PCR and culture of these specimens for Mycobacterium tuberculosis are not consistently positive; consequently, a combination of histopathology, PCR, and culture may need to be performed to confirm the diagnosis (30).

Treatment recommendations for adrenal tuberculosis with drug-susceptible isolates are similar to those outlined for pulmonary tuberculosis in all cases, except for children with miliary tuberculosis, for whom treatment in excess of the standard 6-month regimen is recommended (31). Rifampin induces the hepatic enzymes responsible for the metabolism of steroids, thereby potentially increasing the metabolism of glucocorticoids; aldosterone is less likely to be affected (32-35). Rarely, adrenal crisis has been precipitated by the administration of rifampin (36). There is no consensus on adjunctive treatment with corticosteroids (31).

There are several reports of adrenal recovery when patients receive antituberculosis therapy early in the course of disease, prior to the destruction of the adrenal gland (21, 37-39). Similarly, patients with extra-adrenal infection and blunted adrenal responses to ACTH have experienced improvement in adrenal function in response to antituberculosis therapy (15). With chronic disease, adrenal gland destruction is usually substantial and treatment is unlikely to result in recovery of adrenal function (40). 


\section{THYROID GLAND TUBERCULOSIS}

Tuberculosis uncommonly involves the thyroid gland, potentially due to intrinsic properties of the thyroid gland; the presence of colloid, high blood flow with excess bactericidal iodine, increased phagocytosis associated with hyperthyroidism, and extensive lymphatic and vascular supply to the thyroid have all been postulated as mechanisms (41). In a series of selected patients with late generalized tuberculosis occurring in the pre-and postantibiotic eras, $14 \%$ of patients had evidence of thyroid seeding (42). Tuberculosis has been seen in 0.1 to $1 \%$ of patients with thyroid tissue sampled for any indication (43-45). In a review of 2,426 Moroccan patients with thyroid tissue sampled, only eight had evidence of tuberculosis; five patients had goiter, and three patients had an isolated thyroid nodule (46). More recent assessments have noted thyroid involvement in $0.43 \%$ of specimens obtained from fine-needle aspiration in India and $0.6 \%$ of patients undergoing thyroidectomy in Turkey $(47,48)$.

Tuberculosis of the thyroid can result from hematogenous dissemination or by direct extension from an active laryngeal or lymph node focus. Primary thyroid tuberculosis in the absence of involvement of other organs is extremely rare (44). Five distinct presentations have been described: solitary cold abscess, diffuse goiter (often with caseation), acute abscess, multiple lesions from miliary spread, and chronic fibrosing tuberculosis (49). Miliary disease is the most common presentation, with multiple cold abscesses that mimic the presentation of thyroid carcinoma. Pathologically, tuberculosis causes the formation of epithelioid granulomas, usually with central caseation, Langerhans giant cells, and peripheral lymphocyte cuffing. Acid-fast stains are often positive (50-52).

Tuberculous thyroiditis and bacterial nontuberculous thyroiditis have important differences in their presenting signs and symptoms (53). Patients with tuberculous thyroiditis are less likely to note pain, thyroid tenderness, and fever than are patients with nontuberculous bacterial thyroiditis. Consequently, the duration of symptoms tends to be greater in patients with tuberculosis. In one comparative series, the mean duration of symptoms prior to diagnosis was 105 days for patients with tuberculosis, compared with 18 days for patients with acute nontuberculous bacterial thyroiditis (52). Patients with tuberculosis report a history of thyroid disease less frequently and are more likely to have normal leukocyte counts at the time of diagnosis. Both groups of patients may develop dysphagia, dysphonia, or even recurrent laryngeal nerve palsy related to compression of adjacent structures or fibrosis. These local extra-thyroidal findings may be more common in patients with nontuberculous infections $(53,54)$. Rarely, patients with thyroid tuberculosis may present with fever of undetermined origin (55).

Thyroid function tests are usually normal for patients with tuberculous thyroiditis, but thyrotoxicosis due to rapid release of stored thyroid hormone from the thyroid gland and myxedema caused by thyroid gland destruction have both been reported (44, 50, 52, 56). A review of 76 cases of thyroid tuberculosis found only four cases with evidence of abnormal thyroid function testing (57). The ultrasonographic appearance of tuberculous thyroiditis ranges from solid and heterogenous masses to cystic or hypoechoic lesions (43). CT and MRI findings are nonspecific but may show evidence of intermediate signal on T1 and T2 
weighted imaging or peripheral rim enhancement consistent with abscess $(58,59)$.

Radionuclide thyroid scans typically reveal diminished uptake in the affected tissue (44). Consequently, tuberculous thyroiditis should be considered in patients with solitary cold thyroid nodules after other causes have been excluded, especially in tuberculin-positive patients with normal thyroid function studies.

Fine-needle aspiration for cytology and microbiology is the preferred diagnostic tool for the differentiation of tuberculous thyroiditis from carcinoma and other granulomatous entities, including sarcoidosis, syphilis, and Hashimoto's thyroiditis $(43,44,48)$. The definitive diagnosis of tuberculosis depends upon the demonstration of consistent cytopathological changes with either a positive acid-fast stain or culture for Mycobacterium tuberculosis. In countries with a high incidence of tuberculosis, the diagnosis should be suspected and treatment started if epithelioid granulomas with caseation are found, even in the absence of confirmatory acid-fast studies (43). More recently, PCR has been used to confirm the diagnosis of tuberculosis on pathologic specimens; the sensitivity and specificity are unknown for diagnosis of thyroid gland tuberculosis but are high for other pathologic specimens with tuberculosis (47). Although early definitions of thyroid tuberculosis required the demonstration of an extrathyroidal focus of infection, this requirement has been suspended in view of the more recent recognition of isolated involvement of the thyroid gland.

Many cases of thyroid tuberculosis have been treated with a combination of surgical and antimicrobial therapy. In most cases, surgery has been performed because the presumptive preoperative diagnosis was malignancy. In cases in which thyroidal tuberculosis was treated solely with standard antituberculosis therapy, the response has been favorable, often with resolution of any abnormal results of thyroid function studies $(53,56)$. Treatment regimens are identical to those outlined for adrenal tuberculosis; 6 months of therapy is the standard for most cases of drug-susceptible infection (31).

Thyroid function abnormalities may be noted in patients with active tuberculosis who do not have associated infection of the thyroid gland. Pulmonary tuberculosis is not typically associated with significant alterations in thyroid function, although elevations of free triiodothyronine (T3) and total T3 in response to therapy have been reported (60). In patients who are hospitalized with tuberculosis, the incidence of euthyroid sick syndrome has been substantial, ranging from 63 to $92 \%(13,61)$. The presence of the euthyroid sick syndrome may serve as an indicator of severity of illness, given a significant association between mortality and diminished T3 levels at the time of presentation (61). In that study, results of all thyroid studies were normal for survivors after 1 month of therapy.

Antituberculosis therapy itself may affect thyroid appearance and function. Munkner reported an association between the administration of $p$-aminosalicylic acid and the development of goiter (62). There are also numerous reports of hypothyroidism occurring in patients receiving ethionamide and/or $p$-aminosalicylic acid for second-line treatment of tuberculosis (63-65). In addition, induction of hepatic microsomal enzymes by rifampin may enhance the extrathyroidal metabolism of thyroid hormones, leading to decreased levels of serum-free thyroxine and possibly reverse $\mathrm{T} 3(66,67)$. The impact of rifampin may be 
greater in patients with underlying Hashimoto's thyroiditis, although this finding is extremely rare (67). Practically, these fluctuations are unlikely to significantly affect the patient's clinical course, and there are no reports of thyroid hormone supplementation being required for patients receiving rifampin. Nevertheless, it may be prudent to monitor thyroid functions when patients are being treated with rifampin, ethionamide, and/or $p$ aminosalicylic acid.

\section{PITUITARY GLAND TUBERCULOSIS}

Pituitary gland tuberculosis is rarely seen. In an 11-year pre-antibiotic-era autopsy series involving 14,160 specimens from Cook County Hospital, including 652 cases of pulmonary tuberculosis and 368 cases of tuberculous meningitis, only two specimens yielded evidence of anterior pituitary involvement (68). In the selected group of patients with late generalized tuberculosis, Slavin et al. noted a $4 \%$ incidence of pituitary involvement (42). It is important to note that in many cases, tuberculous involvement of the pituitary is diagnosed purely on pathological grounds, often in the absence of confirmatory microbiology or even of positive acid-fast stains. In a literature review of infections involving the sella turcica, only nine cases included adequate evidence to diagnose tuberculosis definitively (69).

It has been postulated that pituitary tuberculosis can arise from hematogenous seeding, either in the presence or absence of miliary disease, or from direct extension from the sphenoid sinus, brain, or meninges (68). Depending on the pathogenesis, infection can involve the pituitary gland alone or be associated with tuberculosis in an adjacent or distant site.

The clinical presentation of pituitary tuberculosis can vary significantly. Compared with acute nontuberculous bacterial infection, the presentation is typically more indolent (69). Fever is often present. Patients may experience symptoms related to pituitary enlargement, including headache and visual complaints, with or without selective hypopituitarism (6971). Sometimes, selective hypopituitarism occurs in the absence of other symptoms (72). Patients may be relatively asymptomatic, and the endocrine abnormalities may be subtle and noted only on detailed investigation. Any portion of the pituitary (including anterior, posterior, and the stalk) or the hypothalamus can be involved; consequently, presentations can vary and include growth retardation, hypogonadism, galactorrhea-amenorrhea related to excess prolactin secretion, diabetes insipidus, and even panhypopituitarism $(68,70-74)$. Because of the small numbers of cases reported and the incomplete documentation of many of the reported cases, there is not a pathognomonic presentation associated with pituitary gland tuberculosis.

Although hypopituitarism may result from direct involvement of the pituitary gland, it may also occur in association with tuberculous meningitis (75-77). In a prospective study of 75 adult tuberculous meningitis patients in India, the most common abnormalities in pituitary function were hyperprolactinemia (49\%), cortisol insufficiency (43\%), and central hypothyroidism (31\%), with $29 \%$ of patients demonstrating multiple hormone deficiencies (78). According to MRI performed on a small number of patients with a history of tuberculous meningitis and abnormal pituitary function, the pituitary often appeared normal. 
In some cases, third-ventricle dilatation, pituitary atrophy, or enhancement of a portion of the gland or hypothalamus was noted (75).

Pituitary manifestations associated with tuberculous meningitis are variable and unpredictable and may not become apparent until years after recovery. Consequently, the true incidence of pituitary dysfunction following tuberculous meningitis is unknown. In the only detailed assessment of this phenomenon, Lam et al. studied all available patients who experienced tuberculous meningitis prior to the age of 21 years at a single hospital in Hong Kong (75). The investigators were able to locate only 49 of 246 eligible patients, and 10 of 49 patients had evidence of abnormal pituitary function, with growth hormone deficiency being the most common finding.

Infection of the pituitary itself should be suspected when patients with tuberculosis elsewhere present with any signs or symptoms of hypopituitarism. In addition to an assessment of endocrine function, radiologic studies are a useful adjunct to diagnosis. Skull films may demonstrate calcifications in the region of the sella turcica $(75,76)$. Appearance on CT or MRI suggests intrasellar tumor, and angiography results are normal $(69,70,79)$. In some cases, thickening of the pituitary stalk, with or without pituitary extension into the sphenoid sinus, may be noted on CT or MRI $(74,80,81)$.

Definitive diagnosis rests on the pathological demonstration of caseating granulomas with documentation of the organism. Acid-fast stains are often negative; consequently, the diagnosis must also be considered if the patient has a positive tuberculin skin test result or evidence of tuberculosis in another location. Whenever possible, confirmatory cultures should be obtained. The differential diagnosis includes other granulomatous diseases of the pituitary, notably sarcoidosis, histiocytosis X, lymphocytic adenohypophysitis, syphilis, and giant cell granuloma (69).

Because of the association with tuberculous meningitis, lumbar puncture should be performed in patients with clinical signs or symptoms suggestive of meningeal involvement. There are no specific treatment guidelines for pituitary tuberculosis, but given the anatomic location, it seems advisable to follow the guidelines for the treatment of tuberculous meningitis. In case reports where the diagnosis was made premortem, treatment with standard therapy led to resolution of compressive symptoms, with a return to normal pituitary function $(70,79,82)$.

\section{HYPONATREMIA AND SYNDROME OF INAPPROPRIATE ANTIDIURETIC HORMONE}

Disorders of sodium have long been associated with tuberculosis. Infrequently, hypernatremia secondary to diabetes insipidus has been recognized in patients with either pituitary tuberculosis or tuberculous meningitis $(71,74)$. Hyponatremia is more frequently seen in patients with active tuberculosis, with reported incidences of $11 \%, 43 \%$, and $51 \%$ in three large case series (83-85). 
The potential causes of tuberculosis-associated hyponatremia include adrenal insufficiency, the syndrome of inappropriate antidiuretic hormone (SIADH), and cerebral salt wasting. Hyponatremia from adrenal insufficiency is accompanied by hyperkalemia and increased urine potassium excretion, and adrenal function can be assessed by an adrenal stimulation test. When adrenal function is normal, hyponatremia is almost always a consequence of free water intake and retention (inappropriate antidiuresis). SIADH results from ongoing secretion of arginine vasopressin (antidiuretic hormone), from either the pituitary gland or an ectopic site, despite the presence of hyponatremia and extracellular volume expansion (86). Cerebral salt wasting is an alternate explanation for the development of hyponatremia in patients with tuberculous meningitis (87-89).

Weiss and Katz first noted the association of pulmonary tuberculosis with SIADH (90). They observed excessive urinary sodium excretion in four patients with active pulmonary tuberculosis and hyponatremia. With marked fluid restriction, the patients experienced an increase in the serum sodium and decrease in urinary sodium excretion, and all surviving patients experienced normalization of their serum sodium levels during anti-tuberculosis therapy.

Subsequently, several mechanisms have been proposed for the development of SIADH in patients with pulmonary tuberculosis. First, hypoxemia associated with pulmonary tuberculosis may stimulate baroreceptors, leading to arginine vasopressin release from the posterior pituitary gland (91). This relationship would also explain the development of SIADH in other pulmonary diseases characterized by hypoxemia (including acute respiratory failure and chronic obstructive pulmonary disease) (92). A second possibility is a shift in osmoregulation during active tuberculosis (the "reset osmostat"). Hill et al. measured levels of arginine vasopressin in patients with pulmonary tuberculosis (93). Levels of arginine vasopressin were elevated despite the presence of hyponatremia and subsequently declined after the administration of free water. This response to a hyposmolal stimulus suggests that osmoregulation was functioning but at a lower set point for serum osmolality. Finally, ectopic production of arginine vasopressin has been proposed as a third mechanism for SIADH in pulmonary tuberculosis, suggested by a case report of SIADH developing in a pulmonary tuberculosis patient with long-standing diabetes insipidus (94).

As with other infections of the central nervous system, hyponatremia is also seen in a significant proportion of patients with tuberculous meningitis. In a pediatric population with tuberculous meningitis, SIADH was noted in $71 \%$ of patients and appeared to be a predictor of increased mortality rate (95). A study of adult patients with tuberculous meningitis reported SIADH in $45 \%$ of patients (96). An association was observed between SIADH and increased intracranial pressure in children with tuberculous meningitis (97).

The degree of hyponatremia is variable in patients with tuberculosis, and most patients are asymptomatic. In the vast majority of patients, hyponatremia resolves concurrently with response to antituberculosis therapy (93). After volume depletion is ruled out as the cause of hyponatremia, water restriction should be considered only in those patients with severe or symptomatic hyponatremia. Additional pharmacological interventions are generally not 
required. When correction of hyponatremia is indicated for clinical reasons, accepted practice guidelines for the rate of serum sodium correction should be followed (86).

Finally, cerebral salt wasting has been proposed as an alternate explanation for the onset of hyponatremia in patients with tuberculous meningitis (87). Both SIADH and cerebral salt wasting are characterized by hyponatremia, elevated urine osmolality, and elevated urine sodium excretion. However, urine sodium excretion is the putative cause of hyponatremia in cerebral salt wasting, leading to a decrease in extracellular fluid volume (98). This distinction between SIADH and cerebral salt wasting syndrome is difficult to establish given the uncertainty in assessing a patient's extracellular volume status $(99,100)$. There are several reports of successful treatment of suspected cerebral salt wasting in tuberculous meningitis patients with the administration of hypertonic saline and fludrocortisone $(87,88$, 101, 102).

\section{HYPERCALCEMIA}

Tuberculosis is a well-described cause of hypercalcemia. In one large series of patients from Hong Kong, $6 \%$ of patients with confirmed hypercalcemia had tuberculosis (103). The actual prevalence of hypercalcemia in patients with tuberculosis is difficult to estimate, as concurrent serum albumin levels are not always reported. Moreover, the reported rates vary considerably according to geography. Surveys from India, Hong Kong, the United States, Malaysia, and Greece report prevalence rates between 11 and $48 \%$, with the highest rates occurring in the sunniest climates and in patients receiving supplemental calcium and/or vitamin D (5, 104-107). In contrast, surveys from Great Britain, Belgium, and Turkey reported a much lower prevalence of hypercalcemia (108-110).

The majority of the reports of hypercalcemia are for patients with pulmonary tuberculosis, perhaps reflecting the preponderance of pulmonary infection over infection at other sites. Patients with hypercalcemia often demonstrate more extensive pulmonary involvement, but the association with disease severity is inconsistent $(103,104,111)$. Hypercalcemia has been less frequently noted in conjunction with extrapulmonary disease, including miliary infection, peritonitis, and osteomyelitis (111-114). Frequently, hypercalcemia is not noted at the time of diagnosis but occurs early in the course of treatment $(103,111)$. Initial assessments may not account for disease-related hypoalbuminemia, and hypercalcemia may appear only as the serum albumin increases during treatment, reflecting an improvement in nutritional status (115). Hypercalcemia has also developed following the initiation of antiretroviral therapy in patients coinfected with HIV and tuberculosis $(116,117)$.

The mechanism of tuberculosis-associated hypercalcemia remains uncertain. Multiple studies have excluded the common causes of hypercalcemia in these patients, including coexisting hyperparathyroidism, malignancy, adrenal insufficiency, milk-alkali syndrome, and hyperthyroidism (118). According to one possible explanation, hypercalcemia develops as a consequence of increased levels of 1,25-dihydroxyvitamin D in patients with pulmonary tuberculosis. In support of this mechanism, several investigators have reported elevated 1,25dihydroxyvitamin D levels and low to normal 25-hydroxyvitamin D levels for tuberculosis patients with hypercalcemia (119-123). 
In healthy individuals, conversion of 25-hydroxyvitamin $\mathrm{D}$ to 1,25 -dihydroxyvitamin $\mathrm{D}$ by the enzyme 1-alphahydroxylase takes place in the renal tubules. However, hypercalcemia is frequently reported to occur in tuberculosis patients with chronic kidney disease, including patients receiving peritoneal dialysis or hemodialysis (124-126). Tuberculosis-associated hypercalcemia has even been observed in anephric patients $(119,120,122)$. These findings suggest an extrarenal site of production of 1,25-dihydroxyvitamin $\mathrm{D}$ in patients with tuberculosis.

Given that hypercalcemia is also seen in other granulomatous diseases, the granuloma itself may be the site of extrarenal production of 1,25-dihydroxyvitamin D. Macrophages can express the enzyme 1-alpha-hydroxylase, and alveolar macrophages recovered from a patient with active pulmonary tuberculosis were able to synthesize 1,25-dihydroxyvitamin D in vitro $(127,128)$. A study of peripheral blood mononuclear cells taken from patients with active tuberculosis found an increased rate of conversion of 1,25-dihydroxyvitamin D compared to that in peripheral blood mononuclear cells taken from healthy controls (129).

Macrophage production of 1,25-dihydroxyvitamin D modulates the immune response tuberculosis through multiple pathways (130). Binding of 1,25-dihydroxyvitamin $\mathrm{D}$ to the vitamin D receptor induces expression of antimicrobial peptides and stimulates the autophagy pathway, both of which contribute to intracellular killing of M. tuberculosis (131, 132). In addition, 1,25-dihydroxyvitamin $D$ accelerates the resolution of inflammatory responses that may be damaging to the host tissue (133). Increased intestinal absorption of calcium is a by-product of macrophage 1,25-dihydroxyvitamin $\mathrm{D}$ production, leading to the observed association between active tuberculosis and hypercalcemia.

Other studies have questioned the importance of vitamin D in the pathogenesis of tuberculosis-associated hypercalcemia. In clinical trials of patients with active tuberculosis from the United States, Africa, and Belgium, there was no correlation between 1,25dihydroxyvitamin D levels and serum calcium measurements $(109,134,135)$. A systematic review of five clinical trials of vitamin D supplementation during the treatment of tuberculosis did not identify an increased risk of hypercalcemia among patients receiving supplementation (136).

Finally, antituberculosis therapy influences calcium homeostasis. In healthy individuals, both isoniazid and rifampin reduce circulating levels of 25-hydroxyvitamin D and 1,25dihydroxyvitamin $\mathrm{D}(134,137)$. Although long-term administration of both drugs to tuberculosis patients lowered 25-hydroxyvitamin D levels, the effect of the combination was less than anticipated. Furthermore, levels of 1,25-dihydroxyvitamin D were not affected with long-term administration, and as a result the overall clinical impact was insignificant.

With marked hypercalcemia, patients may develop any of the symptoms characteristically associated with hypercalcemia, including lethargy and even metastatic calcifications (114). In most cases, however, hypercalcemia associated with tuberculosis is mild, and patients typically experience complete resolution within 1 to 7 months of antituberculosis therapy without additional intervention (107). 


\section{CORTICOSTEROIDS AND TUBERCULOSIS}

The exact impact of corticosteroid administration on the development and diagnosis of tuberculosis remains somewhat controversial, and the critical dose and duration of corticosteroid exposure associated with tuberculosis reactivation are unknown. In a retrospective study of patients in the United Kingdom receiving corticosteroid treatment for any indication, corticosteroid use within the preceding 6 months was associated with increased odds of developing tuberculosis (138). A population-based study of 6,229 tuberculosis cases in Taiwan over a 12-year period identified a consistent association between corticosteroid use and risk of tuberculosis, with the greatest risk seen among current users of corticosteroids (139).

Other studies have examined disease-specific risk of tuberculosis duration treatment with corticosteroids. Low-risk patients receiving chronic low-dose corticosteroid therapy for treatment of systemic rheumatologic diseases did not have increased reactivation of tuberculosis (140). Higher corticosteroid doses have been associated with reactivation in patients with rheumatic diseases, but the critical dose threshold is unknown (141). Corticosteroid-dependent asthmatics with a history of positive tuberculin skin tests were not at increased risk for the development of active tuberculosis, and use of high-dose inhaled corticosteroids was not associated with reactivation in tuberculin-positive pediatric patients with prior Mycobacterium bovis BCG vaccination (142-144). Finally, there does not appear to be any increased risk for patients with AIDS who are receiving corticosteroids as adjunctive therapy for Pneumocystis jirovecii (formerly carinii) pneumonia $(145,146)$.

Corticosteroid administration can decrease the reliability of testing for latent tuberculosis infection. Healthy adult volunteers who were known to be tuberculin positive were treated with $40 \mathrm{mg}$ of prednisone per day for $1 \mathrm{month}$, and inhibition of the response to tuberculin skin testing began at a mean of 14 days and ended 6 days after suspension of steroid therapy (147). Smaller corticosteroid doses affect skin test responses unpredictably $(143,148)$. Corticosteroid therapy also inhibits the interferon gamma response to $M$. tuberculosis antigens that is the basis of interferon gamma release assays (149). Patients who receive alternate-day corticosteroid therapy generally have preserved responses to tuberculin skin testing $(143,150)$. Of note, patients who are given corticosteroids to treat underlying immunologic disorders may actually experience augmented responses to tuberculin skin testing (148).

According to the official statement from the American Thoracic Society and the Centers for Disease Control and Prevention, targeted tuberculin testing should be performed for all patients who receive more than $15 \mathrm{mg}$ of prednisone daily (or its equivalent) for more than 1 month's duration, with $5 \mathrm{~mm}$ of induration as the criterion for a positive test (151). In patients with positive tuberculin skin testing, there is no contraindication to continuing corticosteroid treatment as required for concurrent illnesses, provided that antituberculosis therapy is also administered (152). Updated guidelines from the Centers for Disease Control and Prevention do not provide a specific recommendation regarding the choice of tuberculin skin testing or interferon gamma release assays for detection of latent tuberculosis infection among patients receiving corticosteroid therapy (153). 


\section{SUMMARY}

The endocrine and metabolic manifestations of tuberculosis are protean. Direct involvement of endocrine glands is only one way in which tuberculosis can affect hormonal and metabolic function. Indirect effects of infection and the impact of treatment on hormonal function must also be considered. Ultimately, treatment plans should be tailored to take into account both the direct and indirect impact of M. tuberculosis infection.

\section{References}

1. Guttman P. Addison's disease: a statistical analysis of 566 cases and a study of pathology. Arch Pathol. 1930; 10:742-745.

2. Betterle C, Morlin L. Autoimmune Addison's disease. Endocr Dev. 2011; 20:161-172. [PubMed: 21164269]

3. Kannan, CR. The Adrenal Gland, vol 2. Plenum Medical Book Company; New York, NY: 1988.

4. Lack, EE., Kozakewich, HPW. Embryology, developmental anatomy, and selected aspects of nonneoplastic pathology. In: Lack, EE., editor. Contemporary Issues in Surgical Pathology, vol 14. Pathology of the Adrenal Glands. Churchill Livingstone; New York, NY: 1990.

5. Lam KY, Lo CY. A critical examination of adrenal tuberculosis and a 28-year autopsy experience of active tuberculosis. Clin Endocrinol (Oxford). 2001; 54:633-639.

6. Alvarez S, McCabe WR. Extrapulmonary tuberculosis revisited: a review of experience at Boston City and other hospitals. Medicine(Baltimore). 1984; 63:25-55. [PubMed: 6419006]

7. Benini F, Savarin T, Senna GE, Durigato S, Vettore L. Diagnostic and therapeutic problems in a case of adrenal tuberculosis and acute Addison's disease. J Endocrinol Invest. 1990; 13:597-600. [PubMed: 2121819]

8. Keleştimur F, Ozbakir O, Sağlam A, Oztürk F, Yücesoy M. Acute adrenocortical failure due to tuberculosis. J Endocrinol Invest. 1993; 16:281-284. [PubMed: 8514984]

9. Cooper MS, Stewart PM. Corticosteroid insufficiency in acutely ill patients. N Engl J Med. 2003; 348:727-734. [PubMed: 12594318]

10. Bancos I, Hahner S, Tomlinson J, Arlt W. Diagnosis and management of adrenal insufficiency. Lancet Diabetes Endocrinol. 2015; 3:216-226. [PubMed: 25098712]

11. Beadsworth MB, van Oosterhout JJ, Diver MJ, Faragher EB, Shenkin A, Mwandumba HC, Khoo S, O’Dempsey T, Squire SB, Zijlstra EE. Hypoadrenalism is not associated with early mortality during tuberculosis treatment in Malawi. Int J Tuberc Lung Dis. 2008; 12:314-318. [PubMed: 18284838]

12. Kaplan FJ, Levitt NS, Soule SG. Primary hypoadrenalism assessed by the 1 microg ACTH test in hospitalized patients with active pulmonary tuberculosis. QJM. 2000; 93:603-609. [PubMed: 10984555]

13. Post FA, Soule SG, Willcox PA, Levitt NS. The spectrum of endocrine dysfunction in active pulmonary tuberculosis. Clin Endocrinol (Oxford). 1994; 40:367-371.

14. Francois, Venter WD., Panz, VR., Feldman, C., Joffe, BI. Adrenocortical function in hospitalised patients with active pulmonary tuberculosis receiving a rifampicin-based regimen-a pilot study. S Afr Med J. 2006; 96:62-66. [PubMed: 16440115]

15. Prasad GA, Sharma SK, Mohan A, Gupta N, Bajaj S, Saha PK, Misra NK, Kochupillai NP, Pande JN. Adrenocortical reserve and morphology in tuberculosis. Indian J Chest Dis Allied Sci. 2000; 42:83-93. [PubMed: 10916272]

16. Zargar AH, Sofi FA, Akhtar MA, Salahuddin M, Masoodi SR, Laway BA. Adrenocortical reserve in patients with active tuberculosis. J Pak Med Assoc. 2001; 51:427-433. [PubMed: 11850979]

17. Laway BA, Khan I, Shah BA, Choh NA, Bhat MA, Shah ZA. Pattern of adrenal morphology and function in pulmonary tuberculosis: response to treatment with antitubercular therapy. Clin Endocrinol (Oxford). 2013; 79:321-325. 
18. Keleştimur F, Göktaş Z, Gülmez I, Unlühizarci K, Bayram F, Ozesmi M, Güven M, Tutuş A. Low dose (1 microg) adrenocorticotropin stimulation test in the evaluation of hypothalamo-pituitaryadrenal axis in patients with active pulmonary tuberculosis. J Endocrinol Invest. 2000; 23:235239. [PubMed: 10853709]

19. Hawken MP, Ojoo JC, Morris JS, Kariuki EW, Githui WA, Juma ES, Gathua SN, Kimari JN, Thiong'o LN, Raynes JG, Broadbent P, Gilks CF, Otieno LS, McAdam KP. No increased prevalence of adrenocortical insufficiency in human immunodeficiency virus-associated tuberculosis. Tuber Lung Dis. 1996; 77:444-448. [PubMed: 8959149]

20. Osborne TM, Sage MJ. Disseminated tuberculosis causing acute adrenal failure, C.T findings with post mortem correlation. Australas Radiol. 1988; 32:394-397. [PubMed: 3202756]

21. Wilkins EG, Hnizdo E, Cope A. Addisonian crisis induced by treatment with rifampicin. Tubercle. 1989; 70:69-73. [PubMed: 2781613]

22. Huang YC, Tang YL, Zhang XM, Zeng NL, Li R, Chen TW. Evaluation of primary adrenal insufficiency secondary to tuberculous adrenalitis with computed tomography and magnetic resonance imaging: current status. World J Radiol. 2015; 7:336-342. [PubMed: 26516430]

23. Buxi TB, Vohra RB, Sujatha, Byotra SP, Mukherji S, Daniel M. CT in adrenal enlargement due to tuberculosis: a review of literature with five new cases. Clin Imaging. 1992; 16:102-108. [PubMed: 1547472]

24. Doppman JL, Gill JR Jr, Nienhuis AW, Earll JM, Long JA Jr. CT findings in Addison's disease. J Comput Assist Tomogr. 1982; 6:757-761. [PubMed: 7119194]

25. Vita JA, Silverberg SJ, Goland RS, Austin JH, Knowlton AI. Clinical clues to the cause of Addison's disease. Am J Med. 1985; 78:461-466. [PubMed: 3976705]

26. Guo YK, Yang ZG, Li Y, Ma ES, Deng YP, Min PQ, Yin LL, Hu J, Zhang XC, Chen TW. Addison's disease due to adrenal tuberculosis: contrast-enhanced CT features and clinical duration correlation. Eur J Radiol. 2007; 62:126-131. [PubMed: 17182208]

27. Zhang XC, Yang ZG, Li Y, Min PQ, Guo YK, Deng YP, Dong ZH. Addison's disease due to adrenal tuberculosis: MRI features. Abdom Imaging. 2008; 33:689-694. [PubMed: 18180983]

28. Wang L, Yang J. Tuberculous Addison's disease mimics malignancy in FDG-PET images. Intern Med. 2008; 47:1755-1756. [PubMed: 18827432]

29. Kumar R, Dey P. Fine-needle aspiration cytology of non-neoplastic adrenal pathology. Diagn Cytopathol. 2016; 44:472-476. [PubMed: 26956774]

30. Gill P, Coatsworth NR, Gundara JS, Hugh TJ, Samra JS. Tuberculosis: experience in a low endemic area Australian tertiary hospital. World J Surg. 2013; 37:984-990. [PubMed: 23397169]

31. Nahid P, Dorman SE, Alipanah N, Barry PM, Brozek JL, Cattamanchi A, Chaisson LH, Chaisson RE, Daley CL, Grzemska M, Higashi JM, Ho CS, Hopewell PC, Keshavjee SA, Lienhardt C, Menzies R, Merrifield C, Narita M, O’Brien R, Peloquin CA, Raftery A, Saukkonen J, Schaaf HS, Sotgiu G, Starke JR, Migliori GB, Vernon A. Official American Thoracic Society/Centers for Disease Control and Prevention/Infectious Diseases Society of America clinical practice guidelines: treatment of drug-susceptible tuberculosis. Clin Infect Dis. 2016; 63:e147-e195. [PubMed: 27516382]

32. Edwards OM, Courtenay-Evans RJ, Galley JM, Hunter J, Tait AD. Changes in cortisol metabolism following rifampicin therapy. Lancet ii. 1974:548-551.

33. Keven K, Uysal AR, Erdogan G. Adrenal function during tuberculous infection and effects of antituberculosis treatment on endogenous and exogenous steroids. Int J Tuberc Lung Dis. 1998; 2:419-424. [PubMed: 9613639]

34. Kyriazopoulou V, Parparousi O, Vagenakis AG. Rifampicin-induced adrenal crisis in Addisonian patients receiving corticosteroid replacement therapy. J Clin Endocrinol Metab. 1984; 59:12041206. [PubMed: 6490796]

35. Schulte HM, Mönig H, Benker G, Pagel H, Reinwein D, Ohnhaus EE. Pharmacokinetics of aldosterone in patients with Addison's disease: effect of rifampicin treatment on glucocorticoid and mineralocorticoid metabolism. Clin Endocrinol (Oxford). 1987; 27:655-662.

36. Yokoyama T, Toda R, Kimura Y, Mikagi M, Aizawa H. Addison's disease induced by miliary tuberculosis and the administration of rifampicin. Intern Med. 2009; 48:1297-1300. [PubMed: 19652434] 
37. Annear TD, Baker GP. Tuberculous Addison's disease. A case apparently cured by chemotherapy. Lancet ii. 1961:577-578.

38. Nordin BE. Addison's disease with partial recovery. Proc R Soc Med. 1955; 48:1024-1026. [PubMed: 13280720]

39. Al-Mamari A, Balkhair A, Gujjar A, Ben Abid F, Al-Farqani A, Al-Hamadani A, Jain R. A case of disseminated tuberculosis with adrenal insufficiency. Sultan Qaboos Univ Med J. 2009; 9:324327. [PubMed: 21509318]

40. Bhatia E, Jain SK, Gupta RK, Pandey R. Tuberculous Addison's disease: lack of normalization of adrenocortical function after anti-tuberculous chemotherapy. Clin Endocrinol (Oxford). 1998; 48:355-359.

41. Chuang TJ, Liu JS, Hung YJ, Hsieh CH. Thyroid tuberculosis. QJM. 2015; 108:47-48. [PubMed: 25078413]

42. Slavin RE, Walsh TJ, Pollack AD. Late generalized tuberculosis: a clinical pathologic analysis and comparison of 100 cases in the preantibiotic and antibiotic eras. Medicine (Baltimore). 1980; 59:352-366. [PubMed: 7432152]

43. Das DK, Pant CS, Chachra KL, Gupta AK. Fine needle aspiration cytology diagnosis of tuberculous thyroiditis. A report of eight cases. Acta Cytol. 1992; 36:517-522. [PubMed: 1636345]

44. Mondal A, Patra DK. Efficacy of fine needle aspiration cytology in the diagnosis of tuberculosis of the thyroid gland: a study of 18 cases. J Laryngol Otol. 1995; 109:36-38. [PubMed: 7876734]

45. Rankin FW, Graham AS. Tuberculosis of the thyroid gland. Ann Surg. 1932; 96:625-648. [PubMed: 17866857]

46. El Malki HO, Mohsine R, Benkhraba K, Amahzoune M, Benkabbou A, El Absi M, Ifrine L, Belkouchi A, Balafrej S. Thyroid tuberculosis: diagnosis and treatment. Chemotherapy. 2006; 52:46-49. [PubMed: 16340200]

47. Gupta N, Sharma K, Barwad A, Sharma M, Rajwanshi A, Dutta P, Sharma A. Thyroid tuberculosis -role of PCR in diagnosis of a rare entity. Cytopathology. 2011; 22:392-396. [PubMed: 21118313]

48. Ozekinci S, Mizrak B, Saruhan G, Senturk S. Histopathologic diagnosis of thyroid tuberculosis. Thyroid. 2009; 19:983-986. [PubMed: 19678750]

49. Khan EM, Haque I, Pandey R, Mishra SK, Sharma AK. Tuberculosis of the thyroid gland: a clinicopathological profile of four cases and review of the literature. Aust N Z J Surg. 1993; 63:807-810. [PubMed: 8274125]

50. Barnes P, Weatherstone R. Tuberculosis of the thyroid: two case reports. Br J Dis Chest. 1979; 73:187-191. [PubMed: 119548]

51. Johnson AG, Phillips ME, Thomas RJ. Acute tuberculous abscess of the thyroid gland. Br J Surg. 1973; 60:668-669. [PubMed: 4724211]

52. Kapoor VK, Subramani K, Das SK, Mukhopadhyay AK, Chattopadhyay TK. Tuberculosis of the thyroid gland associated with thyrotoxicosis. Postgrad Med J. 1985; 61:339-340. [PubMed: 4022867]

53. Berger SA, Zonszein J, Villamena P, Mittman N. Infectious diseases of the thyroid gland. Rev Infect Dis. 1983; 5:108-122. [PubMed: 6338569]

54. Emery P. Tuberculous abscess of the thyroid with recurrent laryngeal nerve palsy: case report and review of the literature. J Laryngol Otol. 1980; 94:553-558. [PubMed: 7400682]

55. Baidya A, Singha A, Bhattacharjee R, Dalal BS. Tuberculosis of the thyroid gland: two case reports. Oxf Med Case Rep. 2015; 2015:262-264.

56. Nieuwland Y, Tan KY, Elte JW. Miliary tuberculosis presenting with thyrotoxicosis. Postgrad Med J. 1992; 68:677-679. [PubMed: 1448412]

57. Bulbuloglu E, Ciralik H, Okur E, Ozdemir G, Ezberci F, Cetinkaya A. Tuberculosis of the thyroid gland: review of the literature. World J Surg. 2006; 30:149-155. [PubMed: 16425087]

58. Kang BC, Lee SW, Shim SS, Choi HY, Baek SY, Cheon YJ. US and CT findings of tuberculosis of the thyroid: three case reports. Clin Imaging. 2000; 24:283-286. [PubMed: 11331157] 
59. Madhusudhan KS, Seith A, Khadgawat R, Das P, Mathur S. Tuberculosis of the thyroid gland: magnetic resonance imaging appearances. Singapore Med J. 2009; 50:e235-e238. [PubMed: 19644607]

60. Ilias I, Tselebis A, Boufas A, Panoutsopoulos G, Filippou N, Christakopoulou J. Pulmonary tuberculosis and its therapy do not significantly affect thyroid function tests. Int J Clin Pract. 1998; 52:227-228. [PubMed: 9744144]

61. Chow CC, Mak TW, Chan CH, Cockram CS. Euthyroid sick syndrome in pulmonary tuberculosis before and after treatment. Ann Clin Biochem. 1995; 32:385-391. [PubMed: 7486798]

62. Munkner T. Studies on goitre due to para-aminosalicylic acid. Scand J Respir Dis. 1969; 50:212226. [PubMed: 4186670]

63. Chhabra N, Gupta N, Aseri ML, Mathur SK, Dixit R. Analysis of thyroid function tests in patients of multidrug resistance tuberculosis undergoing treatment. J Pharmacol Pharmacother. 2011; 2:282-285. [PubMed: 22025859]

64. Munivenkatappa S, Anil S, Naik B, Volkmann T, Sagili KD, Akshatha JS, Buggi S, Sharada MA, Kulkarni S, Chadha VK, Moonan PK. Drug-induced hypothyroidism during anti-tuberculosis treatment of multidrug-resistant tuberculosis: notes from the field. J Tuberc Res. 2016; 4:105-110. [PubMed: 27595122]

65. Thee S, Zöllner EW, Willemse M, Hesseling AC, Magdorf K, Schaaf HS. Abnormal thyroid function tests in children on ethionamide treatment. Int J Tuberc Lung Dis. 2011; 15:1191-1193. i. [PubMed: 21943844]

66. Ohnhaus EE, Studer H. A link between liver microsomal enzyme activity and thyroid hormone metabolism in man. Br J Clin Pharmacol. 1983; 15:71-76. [PubMed: 6849748]

67. Kim DL, Song KH, Lee JH, Lee KY, Kim SK. Rifampin-induced hypothyroidism without underlying thyroid disease. Thyroid. 2007; 17:793-795. [PubMed: 17725438]

68. Kirshbaum JD, Levy HA. Tuberculoma of hypophysis with insufficiency of anterior lobe: a clinical and pathological study of two cases. Arch Intern Med. 1941; 68:1095-1104.

69. Berger SA, Edberg SC, David G. Infectious disease in the sella turcica. Rev Infect Dis. 1986; 8:747-755. [PubMed: 3538314]

70. Ranjan A, Chandy MJ. Intrasellar tuberculoma. Br J Neurosurg. 1994; 8:179-185. [PubMed: 7917089]

71. Rickards AG, Harvey PW. Giant-cell granuloma and the other pituitary granulomata. Q J Med. 1954; 23:425-439. [PubMed: 13215777]

72. Delsedime M, Aguggia M, Cantello R, Chiado Cutin I, Nicola G, Torta R, Gilli M. Isolated hypophyseal tuberculoma: case report. Clin Neuropathol. 1988; 7:311-313. [PubMed: 3224474]

73. Brooks MH, Dumlao JS, Bronsky D, Waldstein SS. Hypophysial tuberculoma with hypopituitarism. Am J Med. 1973; 54:777-781. [PubMed: 4705420]

74. Srisukh S, Tanpaibule T, Kiertiburanakul S, Boongird A, Wattanatranon D, Panyaping T, Sriphrapradang C. Pituitary tuberculoma: a consideration in the differential diagnosis in a patient manifesting with pituitary apoplexy-like syndrome. IDCases. 2016; 5:63-66. [PubMed: 27516966]

75. Lam KS, Sham MM, Tam SC, Ng MM, Ma HT. Hypopituitarism after tuberculous meningitis in childhood. Ann Intern Med. 1993; 118:701-706. [PubMed: 8460856]

76. Sherman BM, Di Chiro G. Postmeningitic selective hypopituitarism with suprasellar calcification. Arch Intern Med. 1971; 128:600-604. [PubMed: 5111666]

77. Beatrice AM, Selvan C, Mukhopadhyay S. Pituitary dysfunction in infective brain diseases. Indian J Endocrinol Metab. 2013; 17(Suppl 3):S608-S611. [PubMed: 24910821]

78. Dhanwal DK, Vyas A, Sharma A, Saxena A. Hypothalamic pituitary abnormalities in tubercular meningitis at the time of diagnosis. Pituitary. 2010; 13:304-310. [PubMed: 20495961]

79. Flannery MT, Pattani S, Wallach PM, Warner E. Case report: hypothalamic tuberculoma associated with secondary panhypopituitarism. Am J Med Sci. 1993; 306:101-103. [PubMed: 8362890]

80. Sharma MC, Arora R, Mahapatra AK, Sarat-Chandra P, Gaikwad SB, Sarkar C. Intrasellar tuberculoma - an enigmatic pituitary infection: a series of 18 cases. Clin Neurol Neurosurg. 2000; 102:72-77. [PubMed: 10817892] 
81. Stalldecker G, Diez S, Carabelli A, Reynoso R, Rey R, Hofmann N, Beresñak A. Pituitary stalk tuberculoma. Pituitary. 2002; 5:155-162. [PubMed: 12812306]

82. Tanimoto K, Imbe A, Shishikura K, Imbe H, Hiraiwa T, Miyata T, Ikeda N, Kuroiwa T, Terasaki J, Hanafusa T. Reversible hypopituitarism with pituitary tuberculoma. Intern Med. 2015; 54:12471251. [PubMed: 25986265]

83. Chung DK, Hubbard WW. Hyponatremia in untreated active pulmonary tuberculosis. Am Rev Respir Dis. 1969; 99:595-597. [PubMed: 5767592]

84. Morris CD, Bird AR, Nell H. The haematological and biochemical changes in severe pulmonary tuberculosis. Q J Med. 1989; 73:1151-1159. [PubMed: 2616737]

85. Jonaidi, Jafari N., Izadi, M., Sarrafzadeh, F., Heidari, A., Ranjbar, R., Saburi, A. Hyponatremia due to pulmonary tuberculosis: review of 200 cases. Nephrourol Mon. 2013; 5:687-691. [PubMed: 23577332]

86. Ellison DH, Berl T. Clinical practice. The syndrome of inappropriate antidiuresis. N Engl J Med. 2007; 356:2064-2072. [PubMed: 17507705]

87. Celik US, Alabaz D, Yildizdas D, Alhan E, Kocabas E, Ulutan S. Cerebral salt wasting in tuberculous meningitis: treatment with fludrocortisone. Ann Trop Paediatr. 2005; 25:297-302. [PubMed: 16297305]

88. Zaki SA, Lad V, Shanbag P. Cerebral salt wasting following tuberculous meningoencephalitis in an infant. Ann Indian Acad Neurol. 2012; 15:148-150. [PubMed: 22566734]

89. Ahmad S, Majid Z, Mehdi M, Mubarak M. Cerebral salt wasting syndrome due to tuberculous meningitis; a case report. J Renal Inj Prev. 2016; 5:53-54. [PubMed: 27069970]

90. Weiss H, Katz S. Hyponatremia resulting from apparently inappropriate secretion of antidiuretic hormone in patients with pulmonary tuberculosis. Am Rev Respir Dis. 1965; 92:609-616. [PubMed: 5833838]

91. Anderson RJ, Pluss RG, Berns AS, Jackson JT, Arnold PE, Schrier RW, McDonald KE. Mechanism of effect of hypoxia on renal water excretion. J Clin Invest. 1978; 62:769-777. [PubMed: 701476]

92. Wong LL, Verbalis JG. Systemic diseases associated with disorders of water homeostasis. Endocrinol Metab Clin North Am. 2002; 31:121-140. [PubMed: 12055984]

93. Hill AR, Uribarri J, Mann J, Berl T. Altered water metabolism in tuberculosis: role of vasopressin. Am J Med. 1990; 88:357-364. [PubMed: 2327423]

94. Lee P, Ho KK. Hyponatremia in pulmonary TB: evidence of ectopic antidiuretic hormone production. Chest. 2010; 137:207-208. [PubMed: 20051406]

95. Cotton MF, Donald PR, Schoeman JF, Aalbers C, Van Zyl LE, Lombard C. Plasma arginine vasopressin and the syndrome of inappropriate antidiuretic hormone secretion in tuberculous meningitis. Pediatr Infect Dis J. 1991; 10:837-842. [PubMed: 1844394]

96. Roca B, Tornador N, Tornador E. Presentation and outcome of tuberculous meningitis in adults in the province of Castellon, Spain: a retrospective study. Epidemiol Infect. 2008; 136:1455-1462. [PubMed: 18205976]

97. Cotton MF, Donald PR, Schoeman JF, Van Zyl LE, Aalbers C, Lombard CJ. Raised intracranial pressure, the syndrome of inappropriate antidiuretic hormone secretion, and arginine vasopressin in tuberculous meningitis. Childs Nerv Syst. 1993; 9:10-15. discussion, 15-16. [PubMed: 8481936]

98. Palmer BF. Hyponatremia in patients with central nervous system disease: SIADH versus CSW. Trends Endocrinol Metab. 2003; 14:182-187. [PubMed: 12714279]

99. Dass R, Nagaraj R, Murlidharan J, Singhi S. Hyponatraemia and hypovolemic shock with tuberculous meningitis. Indian J Pediatr. 2003; 70:995-997. [PubMed: 14719791]

100. Ti LK, Kang SC, Cheong KF. Acute hyponatraemia secondary to cerebral salt wasting syndrome in a patient with tuberculous meningitis. Anaesth Intensive Care. 1998; 26:420-423. [PubMed: 9743858]

101. Camous L, Valin N, Zaragoza JL, Bourry E, Caumes E, Deray G, Izzedine H. Hyponatraemic syndrome in a patient with tuberculosis-always the adrenals? Nephrol Dial Transplant. 2008; 23:393-395. [PubMed: 17951306] 
102. Nagotkar L, Shanbag P, Dasarwar N. Cerebral salt wasting syndrome following neurosurgical intervention in tuberculous meningitis. Indian Pediatr. 2008; 45:598-601. [PubMed: 18695284]

103. Shek CC, Natkunam A, Tsang V, Cockram CS, Swaminathan R. Incidence, causes and mechanism of hypercalcaemia in a hospital population in Hong Kong. Q J Med. 1990; 77:12771285. [PubMed: 2290921]

104. Kitrou MP, Phytou-Pallikari A, Tzannes SE, Virvidakis K, Mountokalakis TD. Hypercalcemia in active pulmonary tuberculosis. Ann Intern Med. 1982; 96:255. [PubMed: 7059082]

105. Liam CK, Lim KH, Srinivas P, Poi PJ. Hypercalcaemia in patients with newly diagnosed tuberculosis in Malaysia. Int J Tuberc Lung Dis. 1998; 2:818-823. [PubMed: 9783529]

106. Roussos A, Lagogianni I, Gonis A, Ilias I, Kazi D, Patsopoulos D, Philippou N. Hypercalcaemia in Greek patients with tuberculosis before the initiation of anti-tuberculosis treatment. Respir Med. 2001; 95:187-190. [PubMed: 11266235]

107. Sharma SC. Serum calcium in pulmonary tuberculosis. Postgrad Med J. 1981; 57:694-696. [PubMed: 7339600]

108. British, Thoracic Association. A controlled trial of six months chemotherapy in pulmonary tuberculosis. First report: results during chemotherapy. Br J Dis Chest. 1981; 75:141-153. [PubMed: 7023526]

109. Fuss M, Karmali R, Pepersack T, Bergans A, Dierckx P, Prigogine T, Bergmann P, Corvilain J. Are tuberculous patients at a great risk from hypercalcemia? Q J Med. 1988; 69:869-878. [PubMed: 3271334]

110. Keleştimur F, Güven M, Ozesmi M, Paşaoğlu H. Does tuberculosis really cause hypercalcemia? J Endocrinol Invest. 1996; 19:678-681. [PubMed: 9007699]

111. Shai F, Baker RK, Addrizzo JR, Wallach S. Hypercalcemia in mycobacterial infection. J Clin Endocrinol Metab. 1972; 34:251-256. [PubMed: 4551069]

112. Braman SS, Goldman AL, Schwarz MI. Steroid-responsive hypercalcemia in disseminated bone tuberculosis. Arch Intern Med. 1973; 132:269-271. [PubMed: 4198181]

113. Lin SM, Tsai SL, Chan CS. Hypercalcemia in tuberculous peritonitis without active pulmonary tuberculosis. Am J Gastroenterol. 1994; 89:2249-2250. [PubMed: 7977256]

114. Wyllie JP, Chippindale AJ, Cant AJ. Miliary tuberculosis and symptomatic hypercalcemia. Pediatr Infect Dis J. 1993; 12:780-782. [PubMed: 8414809]

115. Need AG, Phillips PJ. Pulmonary tuberculosis and hyper-calcaemia. Ann Intern Med. 1979; 91:652-653.

116. Ferrand RA, Elgalib A, Newsholme W, Childerhouse A, Edwards SG, Miller RF. Hypercalcaemia complicating immune reconstitu-tion in an HIV-infected patient with disseminated tuberculosis. Int J STD AIDS. 2006; 17:349-350. [PubMed: 16643687]

117. Lawn SD, Macallan DC. Hypercalcemia: a manifestation of immune reconstitution complicating tuberculosis in an HIV-infected person. Clin Infect Dis. 2004; 38:154-155. [PubMed: 14679464]

118. Abbasi AA, Chemplavil JK, Farah S, Muller BF, Arnstein AR. Hypercalcemia in active pulmonary tuberculosis. Ann Intern Med. 1979; 90:324-328. [PubMed: 426400]

119. Felsenfeld AJ, Drezner MK, Llach F. Hypercalcemia and elevated calcitriol in a maintenance dialysis patient with tuberculosis. Arch Intern Med. 1986; 146:1941-1945. [PubMed: 3767540]

120. Gkonos PJ, London R, Hendler ED. Hypercalcemia and elevated 1,25-dihydroxyvitamin D levels in a patient with end-stage renal disease and active tuberculosis. N Engl J Med. 1984; 311:16831685. [PubMed: 6548798]

121. Isaacs RD, Nicholson GI, Holdaway IM. Miliary tuberculosis with hypercalcaemia and raised vitamin D concentrations. Thorax. 1987; 42:555-556. [PubMed: 3438901]

122. Peces R, Alvarez J. Hypercalcemia and elevated 1,25(OH)2D3 levels in a dialysis patient with disseminated tuberculosis. Nephron. 1987; 46:377-379. [PubMed: 3658068]

123. Saggese G, Bertelloni S, Baroncelli GI, Di Nero G. Ketoconazole decreases the serum ionized calcium and 1,25-dihydroxyvitamin D levels in tuberculosis-associated hypercalcemia. Am J Dis Child. 1993; 147:270-273. [PubMed: 8438806]

124. Hung YM, Chan HH, Chung HM. Tuberculous peritonitis in different dialysis patients in Southern Taiwan. Am J Trop Med Hyg. 2004; 70:532-535. [PubMed: 15155986] 
125. Lee CT, Hung KH, Lee CH, Eng HL, Chen JB. Chronic hypercalcemia as the presenting feature of tuberculous peritonitis in a hemodialysis patient. Am J Nephrol. 2002; 22:555-559. [PubMed: 12381958]

126. Yonemura K, Ohtake T, Matsushima H, Fujigaki Y, Hishida A. High ratio of 1,25dihydroxyvitamin D3 to parathyroid hormone in serum of tuberculous patients with end-stage renal disease. Clin Nephrol. 2004; 62:202-207. [PubMed: 15481852]

127. Cadranel J, Hance AJ, Milleron B, Paillard F, Akoun GM, Garabedian M. Vitamin D metabolism in tuberculosis. Production of $1,25(\mathrm{OH}) 2 \mathrm{D} 3$ by cells recovered by bronchoalveolar lavage and the role of this metabolite in calcium homeostasis. Am Rev Respir Dis. 1988; 138:984-989. [PubMed: 3202473]

128. Tsuganezawa H, Kobayashi K, Iyori M, Araki T, Koizumi A, Watanabe S, Kaneko A, Fukao T, Monkawa T, Yoshida T, Kim DK, Kanai Y, Endou H, Hayashi M, Saruta T. A new member of the HCO3(-) transporter superfamily is an apical anion exchanger of beta-intercalated cells in the kidney. J Biol Chem. 2001; 276:8180-8189. [PubMed: 11102437]

129. Chang K, Lee SJ, Cheong I, Billiar TR, Chung HT, Han JA, Kwon YG, Ha KS, Kim YM. Nitric oxide suppresses inducible nitric oxide synthase expression by inhibiting post-translational modification of IkappaB. Exp Mol Med. 2004; 36:311-324. [PubMed: 15365250]

130. Facchini L, Venturini E, Galli L, de Martino M, Chiappini E. Vitamin D and tuberculosis: a review on a hot topic. J Chemother. 2015; 27:128-138. [PubMed: 26058744]

131. Rockett KA, Brookes R, Udalova I, Vidal V, Hill AV, Kwiatkowski D. 1,25-Dihydroxyvitamin D3 induces nitric oxide synthase and suppresses growth of Mycobacterium tuberculosis in a human macrophage-like cell line. Infect Immun. 1998; 66:5314-5321. [PubMed: 9784538]

132. Liu PT, Stenger S, Li H, Wenzel L, Tan BH, Krutzik SR, Ochoa MT, Schauber J, Wu K, Meinken C, Kamen DL, Wagner M, Bals R, Steinmeyer A, Zügel U, Gallo RL, Eisenberg D, Hewison M, Hollis BW, Adams JS, Bloom BR, Modlin RL. Toll-like receptor triggering of a vitamin Dmediated human antimicrobial response. Science. 2006; 311:1770-1773. [PubMed: 16497887]

133. Coussens AK, Wilkinson RJ, Hanifa Y, Nikolayevskyy V, Elkington PT, Islam K, Timms PM, Venton TR, Bothamley GH, Packe GE, Darmalingam M, Davidson RN, Milburn HJ, Baker LV, Barker RD, Mein CA, Bhaw-Rosun L, Nuamah R, Young DB, Drobniewski FA, Griffiths CJ, Martineau AR. Vitamin D accelerates resolution of inflammatory responses during tuberculosis treatment. Proc Natl Acad Sci U S A. 2012; 109:15449-15454. [PubMed: 22949664]

134. Davies PD, Church HA, Brown RC, Woodhead JS. Raised serum calcium in tuberculosis patients in Africa. Eur J Respir Dis. 1987; 71:341-344. [PubMed: 3443156]

135. Sullivan JN, Salmon WD Jr. Hypercalcemia in active pulmonary tuberculosis. South Med J. 1987; 80:572-576. [PubMed: 3576268]

136. Grobler L, Nagpal S, Sudarsanam TD, Sinclair D. Nutritional supplements for people being treated for active tuberculosis. Cochrane Database Syst Rev. 2016; 2016(6):CD006086.

137. Brodie MJ, Boobis AR, Hillyard CJ, Abeyasekera G, Stevenson JC, MacIntyre I, Park BK. Effect of rifampicin and isoniazid on vitamin D metabolism. Clin Pharmacol Ther. 1982; 32:525-530. [PubMed: 7116768]

138. Jick SS, Lieberman ES, Rahman MU, Choi HK. Glucocorticoid use, other associated factors, and the risk of tuberculosis. Arthritis Rheum. 2006; 55:19-26. [PubMed: 16463407]

139. Lee CH, Lee MC, Shu CC, Lim CS, Wang JY, Lee LN, Chao KM. Risk factors for pulmonary tuberculosis in patients with chronic obstructive airway disease in Taiwan: a nationwide cohort study. BMC Infect Dis. 2013; 13:194. [PubMed: 23631563]

140. Andonopoulos AP, Safridi C, Karokis D, Bounas A. Is a purified protein derivative skin test and subsequent antituberculous chemoprophylaxis really necessary in systemic rheumatic disease patients receiving corticosteroids? Clin Rheumatol. 1998; 17:181-185. [PubMed: 9694048]

141. Kim HA, Yoo CD, Baek HJ, Lee EB, Ahn C, Han JS, Kim S, Lee JS, Choe KW, Song YW. Mycobacterium tuberculosis infection in a corticosteroid-treated rheumatic disease patient population. Clin Exp Rheumatol. 1998; 16:9-13. [PubMed: 9543555]

142. Bahçeciler NN, Nuhoglu Y, Nursoy MA, Kodalli N, Barlan IB, Başaran MM. Inhaled corticosteroid therapy is safe in tuberculin-positive asthmatic children. Pediatr Infect Dis J. 2000; 19:215-218. [PubMed: 10749462] 
143. Schatz M, Patterson R, Kloner R, Falk J. The prevalence of tuberculosis and positive tuberculin skin tests in a steroid-treated asthmatic population. Ann Intern Med. 1976; 84:261-265. [PubMed: 1259260]

144. Shaikh WA. Pulmonary tuberculosis in patients treated with inhaled beclomethasone. Allergy. 1992; 47:327-330. [PubMed: 1443454]

145. Jones BE, Taikwel EK, Mercado AL, Sian SU, Barnes PF. Tuberculosis in patients with HIV infection who receive corticosteroids for presumed Pneumocystis carinii pneumonia. Am J Respir Crit Care Med. 1994; 149:1686-1688. [PubMed: 7911709]

146. Martos A, Podzamczer D, Martinez-Lacasa J, Rufi G, Santin M, Gudiol F. Steroids do not enhance the risk of developing tuberculosis or other AIDS-related diseases in HIV-infected patients treated for Pneumocystis carinii pneumonia. AIDS. 1995; 9:1037-1041. [PubMed: 8527075]

147. Bovornkitti S, Kangsadal P, Sathirapat P, Oonsombatti P. Reversion and reconversion rate of tuberculin skin reactions in correction with the use of prednisone. Dis Chest. 1960; 38:51-55. [PubMed: 13803423]

148. Truelove LH. Enhancement of Mantoux reaction coincident with treatment with cortisone and prednisolone. BMJ. 1957; 2:1135-1137. [PubMed: 13472067]

149. Clifford V, Zufferey C, Germano S, Ryan N, Leslie D, Street A, Denholm J, Tebruegge M, Curtis $\mathrm{N}$. The impact of anti-tuberculous antibiotics and corticosteroids on cytokine production in QuantiFERON-TB Gold In Tube assays. Tuberculosis (Edinburgh). 2015; 95:343-349.

150. MacGregor RR, Sheagren JN, Lipsett MB, Wolff SM. Alternate-day prednisone therapy. Evaluation of delayed hypersensitivity responses, control of disease and steroid side effects. N Engl J Med. 1969; 280:1427-1431. [PubMed: 4306760]

151. American, Thoracic Society. Targeted tuberculin testing and treatment of latent tuberculosis infection. Am J Respir Crit Care Med. 2000; 161:S221-S247. [PubMed: 10764341]

152. Busey JF, Fenger EPK, Hepper NG, Kent DC, Kilburn KH, Matthews LW, Simpson DG, Grzybowski S. Adrenal corticosteroids and tuberculosis. A statement by the Committee on Therapy. Am Rev Respir Dis. 1968; 97:484-485. [PubMed: 4867007]

153. Mazurek GH, Jereb J, Vernon A, LoBue P, Goldberg S, Castro K. Updated guidelines for using interferon gamma release assays to detect Mycobacterium tuberculosis infection-United States, 2010. MMWR Recommend Rep 59(RR-5). 2010:1-25. 